\title{
SOME NOTES ON I.U.F.R.O. AND A FIELD TOUR IN FINLAND ${ }^{1}$
}

\author{
By D. R. REDMOND 2
}

The International Union of Forest Research Organizations (I.U.F.R.O.) began in Vienna in 1890 and now has a membership of over 150 forest research organizations in over 50 countries throughout the world. The aim of I.U.F.R.O. is to develop international co-operation in scientific studies embracing the whole field of research in forestry and forest products. It seeks to facilitate understanding and exchange of ideas and to standardize concepts and methods as far as is desirable, especially through co-operative programs of research, periodical international meetings, standardization of nomenclature and by completing and improving an international Forest Bibliography and Forest Terminology. In addition I.U.F.R.O publishes reviews of research in fields of wide importance.

The President together with a Vice-President and a 12-member Permanent Committee, which meets annually, directs the affairs of the Union. The supreme controlling body is the International Council, which meets every three to five or more years on the occasion of the Congress of the Union, to which every country appoints a representative. Scientific activities are carried on by eleven research sections, each directed by a Section Leader.

The Permanent Committee held its 1963 Annual Meeting in Finland and I was privileged to attend as one of its members. The formal sessions were held in the University of Turku on August 6, 7, and 8. Further meetings were held, August 9 to 17, in conjunction with a forestry tour in southern Finland arranged by government foresters, the University of Helsinki and forest industry.

Two days were spent visiting forestry and industrial establishments in the vicinity of Turku: at Paimio, Tarvasjoki and Naantali. The party then moved to the interior of Finland and spent four days visiting research, training, and industrial establishments at Tampere, Kuru, Vilppula, Mänttä, Hyytiälä, Vanaja. The last day was spent on a study tour of the central laboratory of the Forest Products Industries at Helsinki.

Five days were spent in and around Turku, which is the oldest city in Finland and has a population of around 130,000 . The cathedral and the castle were built 600 or 700 years ago and have been kept in very good repair. However, most of the city was burned within the last century and has been rebuilt to more modern standards, and the buildings now being constructed are similar in design to those being built in any Canadian city. Turku is a sea port and a ship-building centre, as well as the main centre

\footnotetext{
${ }^{1}$ Department of Forestry, Canada, Forest Research Branch, Contribution No. 579.

${ }^{2}$ Director, Department of Forestry, Forest Research Branch, Ottawa.

${ }^{8}$ One Finnish mark equals approximately $36 \mathrm{c}$ Canadian.
} 
for processing food. The country around Turku has been farmed for centuries and all suitable land is under agricultural crops. Non-agrcultural land supports trees. In contrast with eastern Canada, where one-quarter to onethird of cultivated fields may be under grain, in southern Finland approximately $80 \%$ of the fields annually produce grain. All fields are well-drained and the pattern of cultivation interrupted frequently by open ditches is unlike anything that $I$ have seen in Canada.

The City of Tampere, like Turku, also has a population of about 130,000. The former, is a young, highly-industrialized city, referred to by the Finns as their "Manchester" (England). It is quite obvious that the people have an attitude different from that of the people in Turku, and behave much like Canadians.

The Town of Mänttä is a company town and was founded in 1868 when a Swede established a plant for grinding mechanical wood pulp by the side of the rapids on the river. A paper mill was added in 1881. A sulphite pulp mill was built in 1914 and a sulphite alcohol plant in 1918. As in pulp and paper towns in Canada, nearly all the inhabitants depend on the local company for employment.

About one-third of the interior of Finland is water-covered, and there are very few hills higher than $300 \mathrm{ft}$. Roads often follow eskers, which form natural causeways across many of the lakes. As a consequence, the routes followed by buses from one stop to the next provided exceptionally fine scenery. This scenery continued in our southward tour immediately to the limits of Helsinki. Helsinki is the biggest city in Finland and, as the capital, is the seat of government and of the national university. It is also a busy sea port but, like all large European cities, is so diverse, that it would be foolhardy to try to describe it following a visit of one day.

On the whole, the people of Finland are very friendly and hard working. I was informed that the average take-home pay of a woods-worker was the equivalent of $\$ 5.00$ Canadian per day. Many Finns own their own homes, but in the bigger towns and cities, a great number of people live in apartments. The food is rich, mainly meat, butter, eggs and cheese, and those vegetables grown in Finland. Tea and coffee are very expensive, so most people drink milk and buttermilk instead. A bottle of beer is cheaper than a cup of tea or a pot of coffee, and is commonly served with meals. Of course, the famed Finnish institution, the sauna, replaces the bathroom in nearly all homes, and saunas are available to guests at all the better hotels.

Finland is one of the most richly forested countries in the world. About three-quarters of its area is forested-about 54 million acres. This is about 12 acres for each inhabitant. These forests are composed mainly of Scots pine, Norway spruce, and two birches (Betula verrucosa and B. pubescens). Populus tremula is the common aspen. The growing stock amounts to about 1,500 million cubic metres, and the annual growth is about 46 million cubic metres. Ownership of forest area is divided as follows-farmers $62 \%$, the State about $28 \%$, commercial companies about $7 \%$, and the remaining $3 \%$ miscellaneous. About $70 \%$ of the annual growth occurs on privatelyowned forests. 
Since 1960, wood processing industries have been going through a phase of rapid planned development. The growth in pulp production has been about $1,600,000$ tons annually. Of this, about 780,000 tons is absorbed by Finland's paper and paper-board industry, the remainder is exported mainly to western Europe. There is limited export to West Africa, South America, and the United States. The newsprint, paper and paper-board industry is growing at an annual rate of about $400,000,190,000$, and 370,000 tons respectively. This rise in production has increased the total capacity of the pulp and paper industry by about $45 \%$ and will be met only if all the forest land in the country is under forest management. In order to ensure full production several laws have been passed. For example:

"The Law Concerning Private Forests", issued May 11, 1928 reads in part:-

"Forest may not be devastated; and forest may therefore not be felled in such a manner, nor the ground be left in such a state after felling or be treated in such a way that the natural regeneration of the forest is thereby jeopardized."

"Devastation of forest shall likewise be considered to have occurred, if the felling of young vigorous forest is done in a manner that is not consonant with the rational thinning of the forest, or in case an area growing such forest is so burnt-over for cultivation that the burning-over cannot be considered to be consonant with a rational utilization of the area."

The penalty for breaking the law or failing to follow an approved plan of forest management is a fine, unless a higher punishment is enjoined by the penal code, and timber illegally felled, or its value, is forfeited.

There is also a "Forest Improvement Law", which was passed in December, 1957, and reads in part as follows:

"During a period of five years, beginning with the year 1958, there shall be included in the budget a transferable appropriation of at least eight million Finnish marks ${ }^{3}$ to be used for the improvement of forests and for the promotion of timber transportation facilities on privately-owned lands."

This law does not apply to government-owned lands, apart from such lands which may be used for settlement purposes, and the Forest Improvement Funds may not be used for the lands owned by a commune, parish, or a company. However, they do apply to family companies, of which the principal purpose is farming, or associations and foundations connected with farming. Much of this is used for draining and planting peatlands.

Other interesting legislation is contained in the "Act on Forestry Associations", passed in 1950. A Forestry Association is defined as a corporation of forest owners whose aim is improvement of professional forestry knowledge and skill among its members and other forest owners in its district. Also, it should provide professional help to guide and develop silviculture and forest utilization and should promote forestry. Those eligible for membership in the Association are the forest owners with holdings of forest land in the Association's district (on payment of a fee.) A Forestry Association may possess rights and undertake obligations, as well as prosecute and defend in its own name, but it cannot purchase and sell logging rights or timber, or carry on any income-earning activity. 
There are two central Forestry Associations, one for the Finnish-speaking and the other for the Swedish-speaking areas. These lead, supervise, and direct the District Forestry Boards, and through the Boards the activity of the Forest Owners' Associations. They also ensure that matters connected with promotional work come to the notice of the State Board of Forestry, the State Council, and Parliament. One of their main tasks is to ensure compliance with the laws regarding forest drainage, reforestation of areas with deficient production, and the construction of forest motor roads. These Associations employ about 60 forestry officers and 85 foresters.

Under the Central Forestry Association, there are 19 district Forestry Boards - 17 Finnish-speaking and 2 Swedish-speaking. Their main functions are provided by law and are:

1. to supervise observance of the law concerning private forests;

2. to attend to general promotional work for private forestry. The latter is brought about by providing the forest owners with professional assistance, information and instructions on silviculture, timber marking and timber trade, and drawing up plans for management and reforestation. In addition, Boards arrange training activities, forestry competitions, forestry courses and forest excursions. They are self-administering. Four of the members are elected by the Forest Owners' Associations in the area of the Board, and two by the Central Forestry Association, and the General Manager of the total of forest owners. The Forest Owners' Association employ about 19 District Forestry Boards, 135 forest officers and 230 foresters.

Under the District Forestry Boards there are Forest Owners' Associations. These are organizations of forest owners. Their aim is to enhance the professional knowledge and skill in forestry, and the limits of the Association normally cover that of a parish. There are about 380 of these associations and the total membership is about 160,000 . This is thought to be about $60 \%$ of the total of forest owners. The Forest Owners' Association employs about 700 foresters.

Finland's Forest Service was established in 1859 mainly to develop forestry in the country, to study floating of wood, and to promote private forestry and education. There are at present, operated by the Forest Service, 7 schools that provide a two-year course of theoretical and practical knowledge in forestry planning and forestry extension. At one time the University was under the Forest Service, but it is now under the Ministry of Education.

The Forest Research Institute was established in 1917 to conduct investigations and experiments for the development of forestry in Finland. It was reorganized late in 1962 and is under the direction of Dr. E. K. Kalela, whose position is classified as Director and Professor. The Forest Research Institute has seven research departments.

(a) Soils Science: To study silvicultural utilization of soil, its physical and chemical properties, the development of soil and various soil improvement methods.

(b) Peatland: To study silvicultural utilization of swamps, for example, the suitability for draining and afforestation, ecology of swamp forests, the hydrology of the swamps, the effect of various measures on the 
development of swamp forests, and the drainage and other swamp cultivation techniques.

(c) Silviculture: To study forest regeneration and forest thinning methods, forest tree breeding, damage to forests and measures to prevent it.

(d) Forest Biology: To study the morphology, physiology and ecology of forest trees and the mycology, microbiology and plant communities of the forests.

(e) Mensuration and Survey: To study the methods of forest mensuration; the structure, growth, yield and development of tree stands; the principles of forest management; to carry out national forest inventories; to assist the Forest Economics Department in study on forest balance.

(f) Forest Technology: To study, forest work and tools, and the measuring of timber and the properties of wood. This includes seasoning and decay, waterlogging, log size in relation to different types of products, etc.

(g) Forest Economics: To study social economics, business and market questions in forestry and forest industries; to conduct surveys of the drain in forests and its utilization, and assist in performing forest balance studies.

The Forest Research Institute has an Experimental Forests Department, a Nature Conservation office, and a Secretarial-Financial Office. The experimental areas comprise forests in different parts of the country, and amount to more than 160,000 acres. Some of these are parts of Forest Experiment Stations. Visitors to Finland, who are interested in forest research, are normally shown the activities carried on in the area between Helsinki and Vilppula. This area includes the main tree breeding station, the university forest, one of the main swamp research projects, experiments in fertilization, a large area for conducting research on the effects of prescribed burning, and related research on stand development, silviculture, regeneration, mensuration, etc. The advanced program carried out by the Forest Research Institute and also by forest industries is an inspiration to anyone doing research in boreal forests. The staff is very keen, very well trained, and many of them would be able to contribute ably to a research program in Canada if they were to spend even a short period here.

Forests are very important to Finland $-80 \%$ of their foreign exchange is dependent upon forest products. This is reflected by the high esteem in which foresters are held throughout the country. I was told that the Professor of Forestry at Helsinki University is considered the number two citizen of the country - next to the Chief Justice. It is usual for professors of forestry to become rectors and chancellors of universities, and to be members of the Legislature, and special advisers to the President. Canada's dependence upon forestry for its foreign dollar is exceeded only by Finland and Norway, and it seems that foresters in Canada are equally justified in seeking higher prominence and recognition for their profession. 